\title{
Atrial fibrillation, exercise ECHO, OSA, and HOCM
}

In this issue, we have a very comprehensive review of important aspects of the European Society of Cardiology/ Acute Cardiovascular Care Association and the European Heart Rhythm Association Consensus Report on Atrial Fibrillation in Acute Heart Failure submitted by Okutucu and Görenek, from Turkey. We are proud to see Görenek as the first author of this consensus report.

Another important review comes from Belgium, reported by Postolache et al., with Patrizio Lancelotti as the senior, corresponding author. They focused on the use of exercise echocardiography in asymptomatic patients with moderate and severe aortic stenosis with preserved left ventricular ejection fraction. This review will be another important contribution to this topic.

Does an electrocardiogram help in identifying the culprit artery when an angiogram shows both right and circumflex artery disease in inferior myocardial infarction? That is the question explored by Yıldırımtürk et al., from Turkey. This is a challenging issue that needs to be resolved.

Zhang et al., from China, reported on the role of microRNAs in the development and treatment of atrial fibrillation (AF) using patient tissue samples. This study could provide a theoretical basis and potential therapeutic targets for treatment of $A F$.

A strong association between obstructive sleep apnea (OSA) and hypertension is well known. Kaya et al., from Turkey, examined the demographic and polysomnographic differences in OSA patients with and without hypertension, and investigated determinants of hypertension.

Meng et al., from China, submitted their results of examining the effect of surgical resection of muscle layer on the long-term survival of patients with hypertrophic obstructive cardiomyopathy. The number of patients and the long-term follow up make this a study that deserves special consideration.

As always, we have interesting case reports, e-page originals, and more.

I hope this issue of our journal will be of interest of our readers.

Prof. Dr. Çetin Erol

Editor-in-Chief

Ankara-Turkey

Address for Correspondence: Prof. Dr. Çetin Erol, Ankara Üniversitesi Tıp Fakültesi, İbn-i Sina Hastanesi, Kardiyoloji Anabilim Dalı, Ankara, Türkiye

Phone: +9031231033 33/27 79 E-mail: ctnerol@yahoo.com

(C) Copyright 2020 by Turkish Society of Cardiology - Available online at www.anatoljcardiol.com

DOI:10.14744/AnatolJCardiol.2020.6 